\title{
First Generation Minority Students: Understanding the Influential Factors that Contributed to their Preparation and Decision to Pursue Higher Education
}

Alexis Shawnee Palacios Cabrera

Portland State University

Follow this and additional works at: https://pdxscholar.library.pdx.edu/mcnair

Part of the Higher Education Commons

Let us know how access to this document benefits you.

\section{Recommended Citation}

Cabrera, Alexis Shawnee Palacios (2014) "First Generation Minority Students: Understanding the Influential Factors that Contributed to their Preparation and Decision to Pursue Higher Education," PSU McNair Scholars Online Journal: Vol. 8: Iss. 1, Article 2.

https://doi.org/10.15760/mcnair.2014.1

This open access Article is distributed under the terms of the Creative Commons Attribution-NonCommercialShareAlike 4.0 International License (CC BY-NC-SA 4.0). All documents in PDXScholar should meet accessibility standards. If we can make this document more accessible to you, contact our team. 
Running head: FIRST GENERATION MINORITY STUDENTS

First Generation Minority Students: Understanding the Influential Factors that Contributed to their Preparation and Decision to Pursue Higher Education

by

Alexis Shawnee Palacios Cabrera

Faculty Mentor:

Dr. Karen Haley

Cabrera, Alexis S. P. (2014) "First Generation Minority Students: Understanding the Influential Factors that Contributed to their Preparation and Decision to Pursue Higher Education" Portland State University McNair Scholars Research Online Journal: Vol. 8 


\title{
FIRST GENERATION MINORITY STUDENTS
}

\begin{abstract}
The purpose of this research was to explore and understand the experiences of first generation minority students at Portland State University. First generation students are students whose parents have not earned a four-year degree or the equivalence of a bachelor's degree in the United States. By looking at factors that contributed to college decision making process, such as family, peers, high school educators, and high school mentor programs, we can better understand how these factors influence students' experiences. A qualitative analysis was used to assess the responses from 42 students collected through an online survey. This study looked at how these factors influenced students' preparation and decision to pursue higher education. In addition to analyzing specific factors, some motivational themes that emerged from the data included family expectations, financial stability, and personal/career goals. The findings of this study indicate that if parents, students, and school educators are involved then the student develops higher college aspirations and transitions successfully into college. One overall theme in this study emphasizes the importance of tackling students as early as middle school age.
\end{abstract}

Keywords: first-generation, minority 


\section{FIRST GENERATION MINORITY STUDENTS}

\section{Introduction}

Why is an education beyond high school necessary in the United States? With the many economic changes that continue to occur, it is becoming essential in our society to obtain a college education. Recent trends in the U.S. show an increase in the number of minority students graduating high school, "by the year 2020, minority students will account for forty-five percent of the nation's public high school graduates, up from thirty-eight percent in 2009" (Hoover, 2013, p. 16). With the expected increase in minority students graduating, it is important to identify what key factors play a role in the preparation and decision making process to attend college for these students. In order to gain a better understanding we must explore factors such as family, peers, high school educators, and high school mentor programs and how they affect their transition into higher education. One of the biggest problems in higher education is the achievement gaps that exist between students of diverse ethnic backgrounds (Kern, 2010; Pitre \& Pitre, 2009; Herdon \& Hurt, 2004).

More research needs to be conducted on how we can assist students of diverse ethnic backgrounds in providing better access to higher education and how we can increase goal attainment and graduation rates for underrepresented minority students. For this project I chose to work with first generation minority students at Portland State University. A qualitative analysis was used to assess the responses from 42 students collected through an online survey. Responses from each student were assessed using open-coding \& small coding (the examination and breaking down of collected data). The data were then grouped into major themes and categories to represent the experiences of this student population. The question I tried to answer was "How did family, peers, high school educators, and high school mentor programs influence students' decisions and preparation to attend higher education?" The purpose of this study was to gain insight and understanding on the experiences of these students.

\section{Literature}

Because of achievement gaps and small amount of research exploring the preparation and decision making process of these students I looked at three different areas of literature: first generation minority students, mentoring programs, and Alexander Astin's I-E-O Model. The paper focuses on exploring these three areas and how they are important considerations in the preparation and decision making process of these students while pursing higher education.

\section{First Generation Minority Students}

The population that I have chosen for my study is first generation minority students. First generation students are students whose parents have not earned a four-year degree or the equivalence of a bachelor's degree in the United States. First-generation students are "from families with low incomes or from middle- or higher-income families without a college-going tradition" (First Generation Students, para. 2), and are "more likely to be ethnic minority students who speak a language other than English" (Bui, 2002, p. 4). Research conducted by Susan Choy of the Department of Education explains that, "most high school students formalize their education plans between $8^{\text {th }}$ and $10^{\text {th }}$ grade, suggesting that interventions to influence students educational aspirations are most likely to succeed" in pursuing a college education (Choy, 2000, p.4). This suggests that the "development of college aspirations during the middle school grades has the greatest impact on actual college attendance" (C. Pitre \& E. Pitre, 2009, p. 99). One of the overall 


\section{FIRST GENERATION MINORITY STUDENTS}

factors that became apparent is the need to tackle students as early as middle school in their preparation for higher education. I focused on three different components that played a role in the preparation and decision making processes of these students, socioeconomic status (SES), family expectations, and culture.

Socioeconomic Status (SES). Studies have found that, "first generation college students may be less equipped for college due to poor academic preparation from high school and lower critical thinking scores prior to college" (Dennis, Phinney, \& Chuateco, 2005,p. 223). In addition the socioeconomic status of parents is correlated to the achievement of their children. For example, "children whose parents are better educated, make more money, have high status jobs tend to attain higher levels of education than do other children" (Schmid, 2001, p. 73). Students whose parents did not attend college and who come from "low-income families, experience financial barriers are one of and actually delay entry into college" (Wells \& Lynch, 2012, p. 672). Because of the financial barriers that low-socioeconomic status families face, the ability for these families to contribute to educational (tuition) cost are limited and these students are more likely than "higher socioeconomic students to attend under-resourced high schools and receive inadequate college counseling and less likely to attain a degree or receive benefits associated with completion" (Wells \& Lynch, 2012, p. 673). As a result of limited funding and inadequate counsel, low-socioeconomic status students, especially students from diverse ethnic backgrounds, are less likely to attain higher education and are at a higher risk of not "transitioning to college, completing high school, expecting a college degree, and acquiring college qualifications" (Wells \& Lynch, 2012, p. 674).

Family and cultural expectations. Family members are "amongst the most common and important proximal processes for adolescents and young adults and play an important role in academic outcomes" (Dennis et al., 2005, p. 224). However, it is important to assess the different types of expectations that families have. For example, the family expectations for first-generation students (non-traditional) vary from traditional students. For traditional students, "college is what one does after the completion of high school and was simply the next, logical, expected and desired stage in the passage toward personal and occupational achievement" (Terenzini et al., 1994 , p. 62). First generation students do not necessarily have that same expectation because for them going to college was not part of their family's expectations and traditions. In some aspects, "those who were the first in their immediate family to attend college are breaking, not continuing, family tradition" (Terenzini et al., 1994, p.63). Even though families of first generation students of diverse ethnic backgrounds, "lack the first-hand knowledge of the college experience and university system," this does not mean that they are not important influential factors (Dennis et al., 2005, p.233). Despite the lack of first-hand college experience and the university system, families can "instill in their children the expectation of attending college and can provide encouragement and emotional support" (Dennis et al., 2005, p. 224).

Some of the reasons why students purse higher education are influenced by their cultural beliefs and values. The cultural identity of a student can have either a positive or negative effect. Some students may bring a "sense of who they are, where they are from, and seem to retain this different, but non-oppositional social identity" while other students may "develop a new sense of social or collective identity that is in opposition to the new social identity of the dominant group" (Schmid, 2001, p. 76). In other words some students learn to embrace their culture and apply it to their everyday lives while others may adopt a new cultural identity in order to become part of the dominant group.

Another way of looking at the impact of culture is through collectivistic and individualistic perspectives in which both perspectives can be related to attaining a college education. People with a collectivistic approach are "motivated to achieve in order to meet the demands and expectations of others, particularly family members" (Dennis et al., 2005, p. 226). People with an 


\section{FIRST GENERATION MINORITY STUDENTS}

individualistic approach are "more likely to be motivated for personal reasons like the desire to attain a rewarding career" (Dennis et al., 2005 p. 224). The significance of this cultural aspect is how it affects the outcome of student success. In this case success is that they made it to college. Overall, family and culture play a crucial role for the "maintenance of psychological well-being, adjustment, and transition in college for ethnic minority students" (Dennis et al., 2005, p. 226).

\section{Mentoring Programs}

Mentoring is defined as "significant career assistance that is given by more experienced person (s) to less experienced one (s) during a time of transition" (Haring, 1999, p. 9). Mentors can offer support, counseling, coaching, and encouragement to these students. For schools and institutions who work closely with students, the mentor-mentee programs give students the opportunity to work with professionals, receive academic support, and engage in hands-on experiences to increase success (Talbert, 2012, p.23). They can also help students with their transitions in education which means having the ability to progress from one level (e.g., from high school to college). The transition for minority students may consist of "moving from an educational setting in which they are a small percentage of the institutions population and their culture is poorly understood or accepted" (Haring, 1999, p.10). When taking this transition into account, having the support of mentors or advisors can have a great effect on these students in that it can help them "find their way in a new environment gives them the ability to recognize their existence in the field of education" (Talbert, 2012, p. 24).

One of the biggest changes that we are seeing is the increase in high school enrollment and completion rates of students from diverse ethnic backgrounds. It is projected that by the year "2050, about half (approximately $49.4 \%$ ) of the U.S. population will be composed of individuals from diverse ethnic backgrounds" (C. Pitre \& E. Pitre, 2009, p.99). The TRIO educational opportunity program for instance, has been successful in "increasing both higher education attendance rates and educational attainment of students from low income, first generation college, and underrepresented ethnic minority backgrounds" (C. Pitre \& E. Pitre, 2009, p.96). However, there is still a lack of programs available compared to the number of ethnic minority students, resulting in the need for more established programs such as TRIO, Upward Bound, and the Educational Talent Search.

\section{I-E-O Model}

The I-E-O Model serves as the theoretical framework for this study. Alexander Astin's InputEnvironment-Outcome (IEO) Model was used to look at internal and external involvement of these first generation minority students. This theory helped identify the areas and programs that could be improved to increase the educational degree attainment amongst first generation minority students.

Description. Alexander Astin discusses three key issues that are involved in a prospective college student's decision: "(1) whether or not to go, (2) where to go, and (3) how to go" (Astin, 1993, p. 1). In order to adequately observe how these sources impacted the experience of these students, I am using Astin's Input-Environment-Outcome (I-E-O) Model as a theoretical framework. "Inputs" refers to the "characteristics of the student at the time of initial entry to the institution" (Astin, 1993, p. 6). Some examples of inputs can be demographics, family influence, and financial status, and what inspired them to go to college. "Environments" refers to the "various programs, policies, faculty, peers, and educational experiences to which the student is exposed" (Astin, 1993, pp. 6-7). The last aspect of Astin's model is "outcome," which refers to the "student's characteristics after exposure to the environment" (Astin, 1993, p. 7). Outputs can be based on academic, social, and economic outcomes. For example, grade point 


\section{FIRST GENERATION MINORITY STUDENTS}

average (GPA), what students do after college (types of jobs), and community service are all outcomes.

Relevance to my study. For my research I mainly used the "input" portion of Astin's model. Because I am looking at the resources that students receive prior to entering college, taking into account these students demographics, background, and previous experiences is important. This model also helped identify what student success means. For this study student success can be defined as the students making the decision to go to college and actually getting there.

\section{Methodology}

Because of the importance of understanding each of these students and their relative experiences in the preparation and decision making to pursue higher education, a qualitative, survey research design was used. Data were gathered from 42 students from the Diversity and Multicultural Student Services (DMSS) at Portland State University. All the students varied in ethnic backgrounds, grade level, and ages. The methods of this study describe the design, participants (first-generation minority students), procedure, data analysis, and limitations.

\section{Design}

In this study, a survey was used to determine how factors such as family, peers, high school educators, and high school mentor programs influenced students' preparation and decision making process to attend college. The survey was developed using Qualtrics, an online survey program available to students, faculty, and staff of Portland State University. A total of 17 questions including demographic (ethnicity, age, and grade level), yes or no, and open ended questions were used to determine what resources were available to these students prior to entering college (See Appendix A). Students were not required to answer any questions that did not pertain to their experience and even though they were free to skip any questions, it was helpful to the results of the study if all questions were answered to the best of their knowledge. This study includes, but is not limited to just their high school experience. It is important to also consider those students who may not have pursued higher education directly following high school completion, but chose to return after years away from schooling.

\section{Participants}

Participants for this study were all students from Portland State University. Participants were predominantly juniors and seniors, ranging between the ages of 19-53 years old. The recruitment process included approval from the Institution Review Board and the Diversity and Multicultural Student Services at Portland State University. Some of the programs under DMSS include: Diversity Enrichment Scholars, Presidential Equal Access Scholars, TRIO students, Student Leaders and Organizations, and the Multicultural Center. Once the approval was received, the DMSS Advisors and Coordinators forwarded the research project email and survey link to the students on their DMSS list serve. However, for this study the number of students on the DMSS list serve is unknown. I received a total of 43 responses that provided enough relevant information to be used in this study; however of the 43 participants, 42 identified as first generation students while 1 student did not. First generation in this study is defined as students whose parents have not earned a four-year degree or the equivalence of a bachelor's degree in the United States. I also sought out participants who came from diverse ethnic backgrounds including: African Americans, Hispanics, Asian/ Pacific Islanders, Native American, Caucasians, and Multi-Racial individuals. Participants were able to equally access the survey from any computer as long as there was access to the internet. If students had any difficulty accessing a computer from home, they had the 


\section{FIRST GENERATION MINORITY STUDENTS}

option to access it through any computer lab, personal computers, and electronic devices at Portland State University (through available Wi-Fi and computer labs).

Table. 1

Ethnicity

\begin{tabular}{|c|c|c|}
\hline Ethnicity & $\begin{array}{c}\text { \# of students in each } \\
\text { ethnic group }\end{array}$ & $\begin{array}{l}\text { \% of students in } \\
\text { each ethnic group }\end{array}$ \\
\hline Caucasian/ White & 5 & $11.9 \%$ \\
\hline Hispanic/ Latino & 12 & $28.6 \%$ \\
\hline African American/ Black & 3 & $7.1 \%$ \\
\hline $\begin{array}{l}\text { Native American/ American } \\
\text { Indian }\end{array}$ & 0 & $0 \%$ \\
\hline Asian/ Pacific Islander & 10 & $23.8 \%$ \\
\hline Other & 3 & $7.1 \%$ \\
\hline \multicolumn{3}{|l|}{ Mixed Race } \\
\hline Hispanic/ Asian/ Pacific Islander & 1 & $2.4 \%$ \\
\hline $\begin{array}{l}\text { Asian/ Pacific Islander/ Middle } \\
\text { Eastern }\end{array}$ & 1 & $2.4 \%$ \\
\hline White/ Black & 3 & $7.1 \%$ \\
\hline Hispanic/ Black & 1 & $2.4 \%$ \\
\hline White/ Native American & 2 & $4.8 \%$ \\
\hline Hispanic/ Native American & 1 & $2.4 \%$ \\
\hline Total: & & $100.0 \%$ \\
\hline
\end{tabular}

Table. 2

Grade Level

\begin{tabular}{lcc}
\hline Grade Level & $\begin{array}{l}\text { \# of students in each } \\
\text { level }\end{array}$ & $\begin{array}{l}\text { \% of students in each } \\
\text { level }\end{array}$ \\
\hline Freshman & 2 & $5 \%$ \\
Sophomore & 4 & $10 \%$
\end{tabular}


FIRST GENERATION MINORITY STUDENTS

\begin{tabular}{lcc} 
Junior & 13 & $30 \%$ \\
Senior & 23 & $55 \%$ \\
\hline Total & $\mathbf{4 2}$ & $\mathbf{1 0 0 \%}$ \\
\hline
\end{tabular}

Table. 3

Age

\begin{tabular}{ccc}
\hline Age Range & $\begin{array}{c}\text { \# of students in each age } \\
\text { group }\end{array}$ & $\begin{array}{c}\text { \% of students in each age } \\
\text { group }\end{array}$ \\
\hline $18-22$ & 24 & $57 \%$ \\
$23-27$ & 8 & $19 \%$ \\
$28-32$ & 3 & $7 \%$ \\
$33-37$ & 2 & $5 \%$ \\
$38-42$ & 2 & $5 \%$ \\
$43-47$ & 1 & $2 \%$ \\
48 and above & 2 & $5 \%$ \\
\hline Total: & $\mathbf{4 2}$ & $\mathbf{1 0 0 \%}$ \\
\hline
\end{tabular}

\section{Procedure}

The data collection process consisted of three main phases. First, email notifications regarding the research project were sent out to students under the Diversity and Multicultural Student Services Department (DMSS). Each student was provided sufficient information regarding the purpose, potential risk and benefits, incentive, and confidentiality of the study. Participation in this study was entirely voluntary and students had the option to decline participation. The identity of all the participants and their responses were kept confidential and the survey did not ask the participants for any personal identifiers. Second, each student consented to provide information on their personal experiences prior to college. The survey included demographic questions, yes/no questions, and reflective questions. The demographic questions included ethnicity, age, and grade level. The yes/no questions asked if students received support from family, peers, high school educators, and high school mentor programs. If students answered no they could skip to the next question and if they answered yes, there was a follow up question asking how they received support. Third, students filled out the survey to the best of their abilities. Once the survey was closed, I downloaded a copy of the data from the online Qualtrics program into my personal computer, which was password protected to ensure the confidentiality of each participant.

\section{Data Analysis}




\section{FIRST GENERATION MINORITY STUDENTS}

Upon the completion of the survey, the results (student responses) were imported into a Microsoft Excel file. The Excel program allowed me to "easily format and rearrange data to gain new insight, perform complex analysis, compare them and select the options that tells your story best" (Excel, n.d.). Once I imported the data into Excel, I began reading, organizing and sifting through the data. All incomplete data was then eliminated from the excel file. Any incomplete responses were eliminated from the study because they did not provide enough relevant information to be used. I used a system of color coding in order to differentiate and separate each question and response. I went through the data question by question first using open coding (the examination and breaking down of collected data) in order to "take the data and label those categories with a term, or short phrase, mostly based in the actual language of the participant" (Creswell, 2003, p.192). Next, I used the open codes to "generate smaller themes or codes" (Cresswell, 2003, p. 193). Each question had three to four themes associated with the overall responses of the students. After looking at all the themes, I determined that motivation and support became the two overall factors that influence these students preparation and decision making process to attend college. Coding the responses in this manner allowed me to think about what each student said and the meaning (interpretation) behind each response. As I analyzed the data in Microsoft Excel, I also began transferring and explaining the themes and meanings in a Microsoft Word document. I transferred over the themes as well as quotes from each major question in order to describe and strengthen the overall findings and explained what each theme meant and how it supported the data.

\section{Limitations}

This study had several limitations. The first limitation was my connection as a researcher to this study. Because I identify as a first generation minority student, I found that I was able to relate to some of the experiences of these students. At times it was difficult to separate my own experiences and preconceptions from theirs. In order to neutralize my connection to the participants, I had to keep an open mind and not let my personal experiences influence the outcome of the results. The second limitation was related to the participants of this study. The students invited only included students from the Diversity and Multicultural Student Services of Portland State University. Thus, the participants were not fully representative of the larger firstgeneration/ minority student population. Third, because participants were invited by advisors and coordinators of the Diversity and Multicultural Student Services, the participants in this study are more likely than other first-generation minority students to have been successful in pursuing higher education. Fourth, the methodological approach used (qualitative analysis) gave us a wide range of responses, depending on each person's own individual experiences, making the data more complex.

\section{Results}

The results section indicates the themes that emerged from these students' responses and provides an insight into the different experiences that these students went through. This section was organized based on how the survey was organized and includes the following: Initial College Motivators, Educational Support and Guidance, High School Mentor Programs, Family Support and Guidance, Peer Support and Guidance, and Other Support and Guidance. It provides both meaning and interpretation and assesses how family, peers, high school educators, and high school mentor programs influence these students decision to pursue higher education. The section also illustrates some of these students' experiences by including the actual words (responses) of these students.

\section{Initial College Motivators}




\section{FIRST GENERATION MINORITY STUDENTS}

The table below is a breakdown of the responses students gave when asked when they first thought about college. Students had the option from choosing between elementary, middle school, high school, and other. This section also explains why these students decided to go to college.

Table. 4

When did you first think about college?

\begin{tabular}{lcc}
\hline Grade Level/ Other & \# of Student Responses & $\begin{array}{c}\text { \% of student } \\
\text { Responses }\end{array}$ \\
Elementary & 8 & $19 \%$ \\
Middle School & 10 & $24 \%$ \\
High School & 19 & $45 \%$ \\
Other & 5 & $12 \%$ \\
\hline Total: & $\mathbf{4 2}$ & $\mathbf{1 0 0 \%}$ \\
\hline
\end{tabular}

A total of 42 students answered the question about when they first thought about college and of the 42,8 students answered to first thinking about college in elementary, 10 in middle school, 19 in high school, and 5 students provided different answers from the rest of the group. The majority of these students thought about pursuing college in their middle and high school years. After looking at the 5 other responses one student described their experience, "I was a High school dropout. I was studying for GED and impressed myself as to how much I had retained from school and what I had learned unconventionally" while two other students both said they decided to pursue college after "working full-time when there were 19."

Next, students were asked why they wanted to go college. The reasons that students provided include family expectation, hope for a better future for themselves and their families, chance to experience learning and independence, and to pursue their dream jobs. For many attending college was a stepping stone for themselves and their families, they were in a sense role models for others. The overall themes that emerged from these students' responses were family, future financial stability, and personal/ career goals.

For these first generation students, family became a driving force and reason for their pursuit of higher education. To them college was an opportunity that many of their parents did not have the privilege of pursuing, because survival was achieved by working. Parents, siblings, aunts, and uncles all became a source of encouragement for these students; these family members put an emphasis on education and believed in the students' ability to improve their lives. Other reasons why these students went to college include bringing honor to their family and to be the first in their families to get a college education. One student said, "I wanted to go into college so I could make my parents proud," and because "my parents always encouraged me to seek opportunities that would provide a better life for myself."

The next theme that emerged was the importance of attending college for financial stability. Pursuing higher education for these students became essential because they wanted to be able to help their families financially in the future. One student provided a great example: 


\section{FIRST GENERATION MINORITY STUDENTS}

I first wanted to go to college because I thought it would be the way out of poverty. I thought it would be the way I could finally make enough money to help my family out; help them live comfortably for once. I didn't want to struggle in the ways my parents did.

Getting educated can enable these students to explore and engage in opportunities that many of their parents were unable to.

The final theme that emerged from this question was pursuing higher education for personal and career goals. These students saw college as an "opportunity to do something with my life," as a way to "gain understanding of others perceptions," and a "way to achieve my dream job." College was an opportunity to gain knowledge, skills, and tools necessary to pursue future careers and also because students today have more opportunities and options when pursuing a college degree and field of study.

After reading and categorizing the responses, I found that there were several students who had different reasons from the overall group. For them pursuing an education was an outlet or way to keep busy by doing something productive and beneficial, one student said, "I was getting bored at home so I thought that I would try to earn an AA at PCC then I decided I would go for a B.A.," and another student said it "was the right thing to do after high school."

\section{Educational Support and Guidance}

Educational support and guidance in this study refers to what type of educators helped them in high school (teachers, counselors, advisors, etc.) and how these educators helped these students. Students were asked to freely explain their experiences and share how they received support. After analyzing the data, 3 types of support became very influential in these students decisions to pursue higher education.

When students were asked if they received support from high school educators, a total of 40 responded. Of the 40 responses, 30 students answered yes, 7 answered no, and 3 left it blank. For these students preparing for college was difficult because they did not have parents who had the first-hand experience to guide. College was a new experience for them, their families, and friends. Therefore, students depended on their counselors, advisors, teachers, mentors, and even principals for advice, resources, and access to higher education. The themes that emerged from these students experiences are college preparation activities, student engagement, and moral support.

College preparation activities are events or actions that facilitated these first generation minority students to prepare for college. College preparation activities can include: college prep courses and exams, internships, college applications, and financial aid. For these students taking academic courses like writing helped them with their admissions and scholarship applications or participating in workshops helped them connect with other resources. One student describes their experience with Trio and Upward Bound advisors, "they helped me prepare for standardized test, helped me fill out scholarship forms/applications and looked at college catalogs."

Student engagement also became a great source for these students, whether they were involved in high school or college prep programs, participated in campus visits, or made the effort to seek help from their school educators. They took the initiative to seek help and accept help. One student identified several of these factors by explaining that:

The advisors at my school had computers set up in order for students to do research on schools, if we had any questions they would be there to help us. The avid programs were 


\section{FIRST GENERATION MINORITY STUDENTS}

set up at my school in order for students to start prepping for college courses and to learn better techniques in taking notes and studying.

From their engagement they along with their school educators were able to find resources, skills, tips and tools to access higher education.

Lastly, high school educators also provided students with moral support. They encouraged, motivated, and supported their students with their college aspirations. Some educators made the effort work closely with these students and spent extra time in ensuring that these students would have the opportunity to go to college. One student in particular gave a great description of the type of moral support she received:

I found a support network in my high school that consisted of my counselor, teacher, and staff who started talking to me about going to college, and not just talking but signing me up to visit colleges or to go and get involved with things. One teacher in particular helped me out immensely by talking with me and my family about how to get into college and what to do. She helped me with scholarships, connected me to services and so much more.

This is just one example of the dedication and work that these high school educators invested in their students.

Most of the students received many of the same support and assistance from advisors, counselors, some teachers, and high school programs; however, some students' experiences were not as effective as others. One student shared their experience of losing their support system: "I lost my mentors, advisers, friends and community...the support was lost." This students experience navigating the educational system seemed to be done through independence and not so much through support and guidance. However, even though there were some challenges, some students were able to overcome these obstacles in order to move forward-they successfully made it to college.

\section{High School Mentor Programs}

The next part of the survey was to evaluate if students were involved in any mentor programs and how they received support from these programs. After looking at the data, I found that majority of the students in this study were not involved in mentor programs nor received any form of support; however, there was enough data from the students who did receive support to explain the pros of being involved in high school mentor programs.

A total of 42 students answered whether or not they received support from high school mentor programs, and of the 42, 12 answered yes, and 28 answered no, and 2 left it blank. Based on the responses offered there is a recognizable gap between the number of students who were and were not involved in high school mentor programs. Students received the most assistance from school programs including: financial aid, academics, and college engagement activities.

As first generation students, one of the most difficult challenges is being able to pay for a college education because these students generally came from low-income families. For that reason, their high school mentor programs assisted these students in applying for Federal Financial Aid, scholarships, and grants. One student was involved in a program titled, the "Scholarship Mom" program, and she described her experience as:

A program in which mothers of the kids of my high school would volunteer their time to a select few students, most of which were first generation students, to find and apply to 


\section{FIRST GENERATION MINORITY STUDENTS}

scholarships to their colleges. This of course helped me to see that there was additional funding that I had no idea about.

Students also received help in the area of academics. Advisors in the mentor programs helped students prepare for college exams like the Standardized Assessment Test (SAT): "I did SAT prep courses and was introduced to technical colleges and schools that I didn't even know existed, like OIT in Klamath Falls." Advisors also shared their own experiences and knowledge with the students in order to provide them with some insight in the college experience.

Lastly, the mentor programs offered students the opportunity to engage in college engagement activities. These activities included campus visits, tours, and workshops. A student described her experience with a mentor program: "My first two years in high school the mentor program helped me prepare immensely and left a big impact on my young mind." For this particular student, exposure to the college helped her successfully transition into college.

Out of all the responses provided, only one student expressed difficulties that affected their overall experience of the high school mentor program. This student described their experience: "It was not a good program. I was paired up with one mentor who never made time to meet with me. It did not prepare me for college at all." For this particular student, his experience did not prepare him for college like he hoped it would. However, he was the only student who expressed a negative experience with a program.

\section{Family Support and Guidance}

For these first generation minority students', family became a very important reason why they went to college. For many of these students their family's expectations, culture, and livelihood became driving forces in their decision to attend college. Therefore, when the students were asked to indicate if they received support from their families, 30 of them answered yes, 10 answered no, and 2 left it blank. The majority of these students did receive some form and support and it is explained in the section below.

There is no doubt that families play an important role in the lives of these first generation minority students. Their families understood the importance of seeking an education and tried to support their children in the best way they could. Parents and families provided students with motivation and encouragement which influenced the way they viewed education.

Families instilled values, morals and set the foundation for these students, therefore it is important to recognize the connection between the student and their family. In this study families are important because they provided moral, emotional, and financial support to these students. For these students, the transition to college "involves adaptation to a new set of academic and social systems" (Terenzini et al., 1994, p.63).

The encouragement students received is evidence of the type of moral support they got from their families. Their families encouraged them to pursue education, their dream jobs, and to build a better future for themselves. Families instilled a sense of hope and determination, "pushing the vision and opportunity" for these students. For all these students their parents did not have the opportunity to go to college, therefore, their parents really encouraged these students to pursue higher education. One student wrote, "Knowing and experiencing what poverty is my parents encouraged us to go to school." These parents wanted their students to live better, more prosperous lives and they understood that getting an education was one way to achieve that goal.

Emotional support was another big support system for these students. Families stayed by these students to ensure that they were ready and prepared for college. Parents understood what 


\section{FIRST GENERATION MINORITY STUDENTS}

survival meant, and they knew that these students needed them to be there for them, and in some ways it became a learning experience for the families and the students. One student noted her families' emotional support:

Emotional support was huge! My parents went to every meeting, every informational session, and every award ceremony. They knew that they could not support me fiscally but were able to help me by offering me rides to anything, or making me a cup of coffee on late nights anything they could to be there for me. They talked me through every anxiety and problem they could. Also, they tried to inform themselves and understand the college process."

When one thinks of financial support from our families we often think of them paying for tuition, and yes that may be part of it, but these students discussed other ways that they received financial support from family. For these students, financial help was not all about paying for their tuition, to them it was being able to live at home while they went to school without having to move out and pay rent elsewhere. For one student financial support from their family was "letting us live with them; let us have plenty of time to do homework: / did not force us to work or pay for bills/food." For this student having their family support enabled them to pursue a college education.

\section{Peer Support and Guidance}

Because these students are first in their families to go to college, relying on peers as a support system became apparent in their success and transition into college. For these students peer support and guidance was a huge part of their transition to college. Peers provided social, academic, and emotional support system for these students.

Peers provided tips and resources for access to college, scholarships, and in some cases went through the application process together. By having friends who are going through the same or similar experience it makes it easier to connect and network with one another. In this way peers then served as a social system for one another, most especially having friends who also were working towards transitioning into college. They worked together to navigate the college process and with that they formed their very own social support system. One student discussed her experience with her peers:

My peers were a huge part of my support. Applying to college was a new process to all of us because none of us had parents that went to college. They supported me by doing research in the colleges we) had planned to apply to, attend college information nights with me, and we all visited colleges to get to know the college more.

Peers also provide academic support towards one another. Whether it was through helping each other study, encouraging each other to apply for college, or getting involved in college preparation activities. They explored career options together and discussed their plans. They shared tips, advice, and directions towards applying for schools, financial aid, and scholarships. For one student they described their peer experience as being "able to network and find out about classes, professors, programs and jobs."

The last theme that emerged from peer support was emotional support. Peers of these students believed in their friend's capabilities, and saw potential in them. Their peers encouraged these students to pursue college. As one student said, "They supported me by cheering me on and motivating me to apply for college." The belief that peers had in these students influenced their decision and preparation to attend college.

\section{Other Support, Guidance and Comments}




\section{FIRST GENERATION MINORITY STUDENTS}

At the end of the study, students were asked if they had any other sources of support, guidance, and or comments to add. The students gave a variety of answers, some of which included the previous sources (family, peers, high school educators, and high school mentor programs). Other students shared part of their stories in how they made it to college, and what they experienced to get to college.

These students discussed how family members like aunts, uncles, and siblings influenced them based on their personal experiences in higher education. Others went through life experiences where they struggled in the job market, and through those struggles they were encouraged to go back to school. One student talked about how they pursued higher education because "I was motivated as a single father to lead by example," while another student said, "it was a self-desire." Because all of these students are non-traditional students they faced difficulties in accessing and going through the process of transitioning into college, for some it was a journey on their own. Another student talked about how much they appreciated the support that they received:

I am in college now because some incredible people cared enough to take the time and cared enough to get me into college. I stayed in college because the tools that these people gave me I was able to develop and use long after my high school time had ended.

Because all of these students are non-traditional students they faced difficulties in accessing and going through the process of transitioning into college, for some it was a journey on their own. Some students had to independently pursue their education because they did not have much support or help. One student explained their experience:

To be honest, not really. The jobs I had blatantly discouraged me from limiting my availability to work by going to school. This made it much more difficult to pursue an education on my own. I was on my own as a teenager, so it was always out of reach financially.

This student may have been independent and out of reach financially, but they managed to find other ways to get to college.

\section{Discussion}

The results of this study indicate that there is great potential in increasing the number of first generation minority students in higher education. The participants in this study can all be classified as successful students in that they are all in college. By having family involvement, support from educators, and encouragement from others these students showed their ability to succeed in college.

First-generation students are identified as students whose "parents had not attended college; reducing the likelihood of going to college, and increasing the risk of dropping out of high school" (Choy, Laura, Nunez, \& Chen, 2000). However, data now indicates that "more and more students whose parents have not attended college are pursuing higher education" (Bui, 2002, p.3). Based on the results of this study, motivation and support became the two overall themes that influence these first generation minority students in their preparation and decision making to pursue higher education. Because first generation students have a harder time transitioning from high school to college, receiving motivational support in the form of encouragement from family, peers, and educators became a guiding source in their ability to attend college. For these students it was the fact that others believed in their potential that helped prompt them to go to college. Those who provided moral support helped inspire and influence these students to make something of their lives. It showed them that they could be anything or anyone they wanted to be, just as one student described that they wanted to go to college "to achieve my dream job of being a television 


\section{FIRST GENERATION MINORITY STUDENTS}

show presenter/reporter." This means that the encouragement they received influenced the development of future career aspirations.

For their families, going to college grew into an expectation even though college was outside of their tradition. Even though these students' parents never earned their Bachelor's degrees, their parents made the time and effort to stay alongside their child and go through the college process with them. Parents also instilled in their children the importance of going to college to build a better future for themselves and their family. In return going to college was seen as a great accomplishment for their families, peers, and community. To the students it meant being able to provide for themselves and their families future security, making them proud, and bringing honor to them. To their peers motivating each other became a learning and driving experience.

Though the literature indicates that these students are "less equipped for college due to poor academic preparation," the results of this study show that these students were capable of preparing themselves academically. For example, peers learned to work together by taking college prep course, filling out college applications, and even engaging in campus visits and workshops. They built a networking system, shared tips and advice, and helped one another access resources to help with the college transition. For their high school educators and high school mentor programs, having their students go to college meant that they did their job, that they had an impact on the lives and goals of their students. The fact that their students made it to college became a reward, a sense of achievement and success in their roles as educators.

Besides receiving motivation, these students also received various forms of support. The forms include, moral, emotional, financial, social, and academic support. Through these support systems, these students were able to make that transition into college successfully. Indeed, these students may have not attended the best schools or had the best programs to prepare them college, however, they still successfully made it to college. The only difference is that these students did not have parents with a college education. Though the literature indicates that students whose parents are educated and come from higher income families tend to attain higher levels of education, the students in this study indicate otherwise. With that said, it just meant that they needed to work harder to access the necessary resources to help prepare them. In fact, students showed much gratitude for the support they got and gave great examples of the types of assistance they received. For example, these students knew that their parents may have not been able to afford the cost of tuition; however, that did not prevent them from seeking an education. In retrospect, families did whatever they could to provide some kind of assistance to these students, whether it was continuing to put a roof over their heads or food on the table, they did it. This is evidence that the Socioeconomic Status of parents is not always correlated to the achievement of their children. Family members also attended campus visits and tours, meetings, and workshops. By attending these activities, families "increased the odds of students enrolling in college, than for those whose parents had little or no discussion with them" (Choy S. et. al, 2000). This showed the families commitment to ensure that these students would have a better future.

Peers came together in helping one another research colleges and institutions. They helped each other fill out and look for financial aid, scholarships, and grants. Peers networked with one another by recommending professionals who could assist with the college preparation process. Finally, friends understood the importance of an education and also showed support by believing in each other's career aspirations and goals.

High school educators and programs offered services that allowed students to participate in college prep classes, advising, and college engagement activities. These educators were able to share their personal experiences of the expectations, environments, and adjustment processes of college. When educators become involved in developing college aspirations with these students as early as middle school they help increase the likelihood that these students will pursue higher education. 


\section{FIRST GENERATION MINORITY STUDENTS}

\section{Implications}

Based on the results of this study, there is significant evidence indicating that if first generation minority students are supported and encouraged by their families, peers, high school educators, and high school mentor programs, the likelihood of transitioning from high school to college is increased. After looking at the experiences of these students it is evident that these students have as much potential to attend college as do other students as long as they have the personal motivation and support to do so. So the question is what can we do in order to better prepare and increase access for these first generation minority students in their pursuit of higher education? I think this may be your research question!!

We need to promote the importance of college engagement activities and recruitment of first generation students from diverse ethnic backgrounds. When students are actively engaged in activities that will expose them to the expectations, information, and knowledge of the college experience students are better prepared for their transition. By giving them an insight to what higher education can offer, students can better determine what school, major, or career they would like to pursue.

Participating in campus visits, workshops, preparatory, and recruitment programs, students will be better prepared for the college transition. Through college engagement activities students and their peers can begin networking and connecting with important campus resources including admissions, financial aid, and academic advising. Through such activities students can begin the research processes for schools, scholarships, and academic programs; they can "receive their first introduction to the attitudinal and behavioral norms of a new academic and social setting" (Terenzini et al., 1994).

We also need to emphasize the importance of family involvement for first generation minority students. The evidence "strongly indicates that parents/spouses play a key role in the support of new students adjusting to a new environment" (Terenzini et al., 1994). Though the parents of these students do not have a 4-year degree or the equivalence of a Bachelor's degree in the U.S., they were able to support their children beyond expectation. Parents may not have had the first-hand college experience but they still provided encouragement, moral, emotional, social, and financial support to these students.

The data suggest that family members provided the most encouragement for these students to pursue high education. Therefore we need to conduct more research on the relationships of students, most especially first generation minority students. Just as it is necessary for students to familiarize themselves with resources to access college, it is also vital that families also familiarize themselves with those same resources so that they too can encourage these students to utilize these resources.

\section{Conclusion}

The preparation and decision to go to college is one that entails research, access to resources, support, and most of all the motivation. For this reason, it is important to understand who, what, why, and how these 42 first generation minority students have successfully pursued higher education. Based on this study, I have found that family, peers, high school educators and mentor programs all influenced these students' decisions to go to college. Today, students from diverse ethnic backgrounds are still less likely to attend institutions of postsecondary education and with the expected increase of "high school enrollment and completion rates of high school students from ethnic minority backgrounds" (C. Pitre \& E. Pitre, 2009, p.99). Thus, it is important that we continue doing research on these student population groups. For example, increasing and 


\section{FIRST GENERATION MINORITY STUDENTS}

expanding educational/ developmental mentor programs like TRIO, Upward Bound, and Student Support Services in order to accommodate the growing ethnic minority populations.

\section{Appendix A: Survey Questionnaire}

\section{Directions: Please answer each question as completely as possible.}

\section{Demographic information}

1. Are you a first generation student? (Neither parent has earned a four year degree (Bachelor's Degree) in the U.S.).

Yes No

2. Ethnicity origin (or Race): Please specify all that apply.

- Caucasian

- Hispanic or Latino

- Black or African American

- Native American or American Indian

- Asian/ Pacific Islander

O Other (please specify)

3. What is your age?

4. What is your grade level? (please specify)

$\begin{array}{ll}\circ & \text { Freshmen } \\ \circ & \text { Sophomore } \\ \circ & \text { Junior } \\ \circ & \text { Senior }\end{array}$

5. When did you first think about going to college (i.e., elementary school, middle school, high school, after graduation)?

\section{Initial College Motivators}

6. What was it that first made you think about college (i.e., person, event, program)? Explain the situation; you may include more than one example.

7. Why did you first want to go to college?

\section{Educational Support and Guidance}

8. Did your school educators (i.e., teachers, counselors, advisors) support you in going to college?

Yes No

9. If yes, how did your school educators support you in preparing for college? Be specific. 


\section{FIRST GENERATION MINORITY STUDENTS}

10. Where you involved in any mentor programs?

Yes No

11. If yes, how did the mentor program help you in preparing to go to college?

\section{Family Support and Guidance}

12. Did your family support you in preparing you for college?

Yes No

13. If yes, how did your family support you in preparing for college?

Peer Support and Guidance

14. Did your peers support you in preparing for college?

Yes No

15. If yes, how did your peers support you in preparing for college?

\section{Other Support and Guidance}

16. Explain any other sources of support and guidance as you prepared for college.

17. Any other comments that you want to add to explain your journey to college. 


\section{FIRST GENERATION MINORITY STUDENTS}

\section{References}

Astin, A. (1993). What matters in college? San Francisco: Jossey-Bass Inc.

Bui, K. V. (2002). First-generation college students ar a four-year university: background characteristics, reasons for pursuing higher education, and first year experiences. College Student Journal,36(1).

Kern, C.W. (2010). College choice influences: Urban high school students respond. Community College Journal of Research and Practice,24(6), 487-494.

Choy, S. P. (n.d.). Students whose parents did not go to college: Postsecondary access, persistence, and attainment. Retrieved from National Center for Education Statistics: Retrieved from http://0-nces.ed.gov.opac.acc.msmc.edu/pubs2001/2001072_Essay.pdf

Choy, S. P., Horn, L. J., Nuñez, A.-M. and Chen, X. (2000), Transition to College: What Helps AtRisk Students and Students Whose Parents Did Not Attend College. New Directions for Institutional Research, 2000: 45-63. doi: 10.1002/ir.10704

Creswell, J. W. (2003). Research design qualitative, quantitative, and mixed methods approaches. Thousand Oaks: Sage Publications.

Dennis, J. M., Phinney, J. S., \& Chuateco, L. I. (2005). The role of motivation, parental support, and peer support in the academic success of ethnic minority first-generation college students. Journal of College Student Development, 46(3), 223-236.

First Generation Students . (n.d.). Retrieved from College Board: http://professionals.collegeboard.com/guidance/prepare/first-generation

Haring, M. (1999). The case for a conceptual base for minority programs. Peabody Journal of Education, 74(2), 5-14. Retrieved from EBSCO Host. Web. 12 Mar. 2013.

Herndon, M.K., Hirt, J. B. (2004). Black students and their families: What leads to success in college. Journal of Black Studies, 34, 489-513. doi:10.1177/0021934703258762

Hoover, E. (2013, February 14). Minority applicants to colleges will rise significantly by 2020. Chronicle of Higher Education, 59(19), A16-A17.

Pitre, C. C., \& Pitre, P. (2009). Increasing underrepresented high school students' college transitions and achievements: TRIO educational opportunity programs. Sage Publications.

Schmid, C.L. (2001). Educational achievement, language-minority students, and the new second generation. Sociology of Education, 74, 71-87

Talbert, P. Y. (2012). Strategies to increase enrollment, retention, and graduation rates. Journal of Developmental Education, 36(1), 22-36.

Taylor-Powell, E., \& Renner, M. (2003, July 12). Analyzing qualitative data. Retrieved from University of Wisconsin-Extension Cooperative : http://learningstore.uwex.edu/assets/pdfs/G3658-12.PDF

Terenzini, P.T., Rendon, L.I., Upcraft, M.L., Millar, S.B., Allison, K.W., Gregg, P.L., \& Jalomo, R. (1994). The tranisition to college: Diverse students, diverse stories. Research in Higher Education,35(1), 57-73.

Wells, R., \& Lynch, C. (2012). Delayed college entry and the socioeconomic gap: Examining the roles of student plans, family income, parental education, and parental occupation. The Journal of Higher Education, 83(5), 672-694. Retrieved March 13, 2013, from http://muse.jhu.edu/journals/journal_of_high 